\title{
A CRITICAL ANALYSIS OF INDIAN TEXTILE INDUSTRY: AN INSIGHT INTO INCLUSIVE GROWTH AND SOCIAL RESPONSIBILITY
}

\author{
Pankaj Dixit ${ }^{\star}$, Assistant Professor \\ Department of Accounting and Finance, Lebanese French University, Erbil, Kurdistan (Iraq) \\ Lal R.C., Professor, Dr. \\ Multanimal Modi College, Modinagar \& Chaudhary Charan Singh University, Meerut, India
}

*E-mail: pdixit2989@gmail.com

\begin{abstract}
Textile industry has been a symbol of India's cultural heritage, which has worked to connect the people and played an important role in their economic interests. This sector is mainly divided into several disciplines at the unorganized level, it has made its identity as a cottage industry in every state of India. In the present paper, the textile industry has been focused on inclusive development and social obligations. The main purpose of this paper is to see how the textile sector is contributing in inclusive development. In order to reach the conclusions, both primary and secondary data has been analyzed in qualitative analysis. Finding of this research reveals that the textile is contributing towards employment generation and inclusiveness but in terms of social responsibility it is not playing positive role because of its unorganized structure.
\end{abstract}

\section{KEY WORDS}

Textile industry, inclusive growth, corporate social responsibility, unorganized sector, cottage industry.

The Indian Textile Industry represents a rich and diverse spectrum of activities with the hand-woven sector on with the hand-woven sector on one end and the capital intensive mill sector on the other. The spectrum includes activities in the decentralized power looms, hosiery and knitting sectors, the handicrafts segments and also covers a wide range of fibers which include man-made fibre, cotton, silk, jute and wool. The Indian textile sector is unique in comparison to that of other countries owing to the close linkage of the industry to agriculture and also due to linkage with the culture and traditions of the country. India is the largest producer of jute in the world. It contributing India has a long tradition and culture integrated with textile. Our civilization which had progressive through vast phases has an immense contribution of textile and cottage industry. India so called a "golden bird" before foreign invaders. The reason itself lies in inclusive societies that have economic equity.

The main cause of economic inequality is rapid growth of population. Textile sector is providing employment to the people at a very large level in facing the challenges of inclusive growth in countries like India. It is one of the oldest industries in the Indian economy, which has been making its identity in the form of cottage industries for many centuries. India's aggregate textile exports in the fiscal year 2017-18 were US $\$ 39.2$ billion. This industry is basically dependent on the raw materials produced from agriculture. India is the second largest producer of textile in the world and is the third largest producer of cotton and also the largest consumer of cotton consumption after US and China. It is providing the highest employment after agriculture sector.

In the world's leading exporters, the Indian textile sector has made a unique identity. But its unorganized structure allows it to push something backward at the technological level, mainly due to the inadequate finance capital. At present, due to cheap labor -cost in countries like Bangladesh, cost competition has increased. In every state of India, the textile is conserving its legacy as many dimensions, it is the basic needs of livelihood of people in every region of India from north to south and east to west. In the empowerment of women, 
the textile is fulfilling their economic needs. Women are being financially contributing to the family by the consuming time in textile related work at home. Even girls teenager are also learning artistic textile skills and earning the money in free time after the school. So, overall it is inclusively contribute towards the socio-economic goals of the nation.

The main aim of the research is to study the textile industry through the prism of the inclusive growth and social responsibility. It investigates the role of the textile firm to achieving the inclusive development without compromising the social responsibility:

To find out the current problem and solution of unorganized textile workers;

To find out the data regarding textile this is not officially available;

To know about the social responsibility of unorganized sector for its employee welfare;

To know the environmental issues regarding textile informal sector;

To find out the contribution of unorganized sector in employment generation.

\section{METHODS OF RESEARCH}

This paper is trying to find the real meaning of inclusive growth in true manner. For this purpose, primary data and secondary data have been used in both quantitative and qualitative manner to reach the conclusion of this research. Secondary and primary data have been collected from the reliable sources. For analyzing the data, critical evaluation thoughts and SPSS tool has been used.

\section{RESULTS AND DISCUSSION}

Structure of Indian Textile Industry. Indian textile has started from small houses and now become the main stream of the economy, for the development of this cottage industry (Kuteer Udyog), the Indian government has established the ministry of textile on central level and state level \& which run under the umbrella of the MSME (Micro small \& medium enterprises) department. Indian textile has been divided into an organized and unorganized sector, but its unorganized structure reflects the diversity of its inclusive policies.

To develop the clothes products, textile industry follow mainly three steps as, spinning, weaving, finishing, apparel making. The participation of major textile industries are only $3 \%$ of total. In current scenario only 276 small medium and big mills are running in different region of India. This low participation of the major textile industry is due to negligence of the government.

The Sericulture and Silk Sector. In silk farming production, India stood on second place and producing $18 \%$ silk of total world production. India has the distinctive distinction of being the sole country manufacturing all the 5 noted industrial silks, namely, mulberry, tropical tasar, oak tasar, eri and muga, of that muga with its golden yellow glitter is exclusive. Mulberry sericulture is especially practiced in 5 states specifically, Karnataka, province, Assam and Bodoland, province, Jharkhand and state are major silk manufacturing states within the country. North East has the distinctive distinction of being the sole region manufacturing four styles of silk viz., Mulberry, Oak Tasar, Muga and Eri. Overall NE region contributes eighteenth of India's total silk production. India is that the second largest producer of silk within the world. Among the four styles of silk made in 2015-16, Mulberry accounts for seventy one.8\% (20,434 MT), Tasar 9.9\% (2,818 MT), Eri 17.8\% (5,054 MT) and Muga zero.6\% (166 MT) of the entire raw silk production of twenty eight,472 MT. The demand for superior quality bivoltine silk is increasing in Asian country for domestic consumption moreover as price other silk product for the export market. The Ministry of Textiles Government, Departments of Sericulture in numerous states offer technical and monetary help for enhancing the bivoltine silk production.

Composition of Indian textile. The textiles sector includes the organized Cotton and non-mechanized Fibre Textiles Mills. The non-mechanized Fibre and Filament Yarn business, the Wool and Woollen Textiles, the Sericulture and Silk Textiles, Powerlooms, Handlooms, Handicrafts, the Jute and Jute Textiles, and attire \& clothes and textile also are the a part of Indian Textile business. 
The following are also the part of this industry:

1. Spinning and weaving;

2. Knitting and Hosiery;

3. Garmenting;

4. Processing dyeing and finishing;

5. Instrumentation and IT;

6. Auxiliaries.

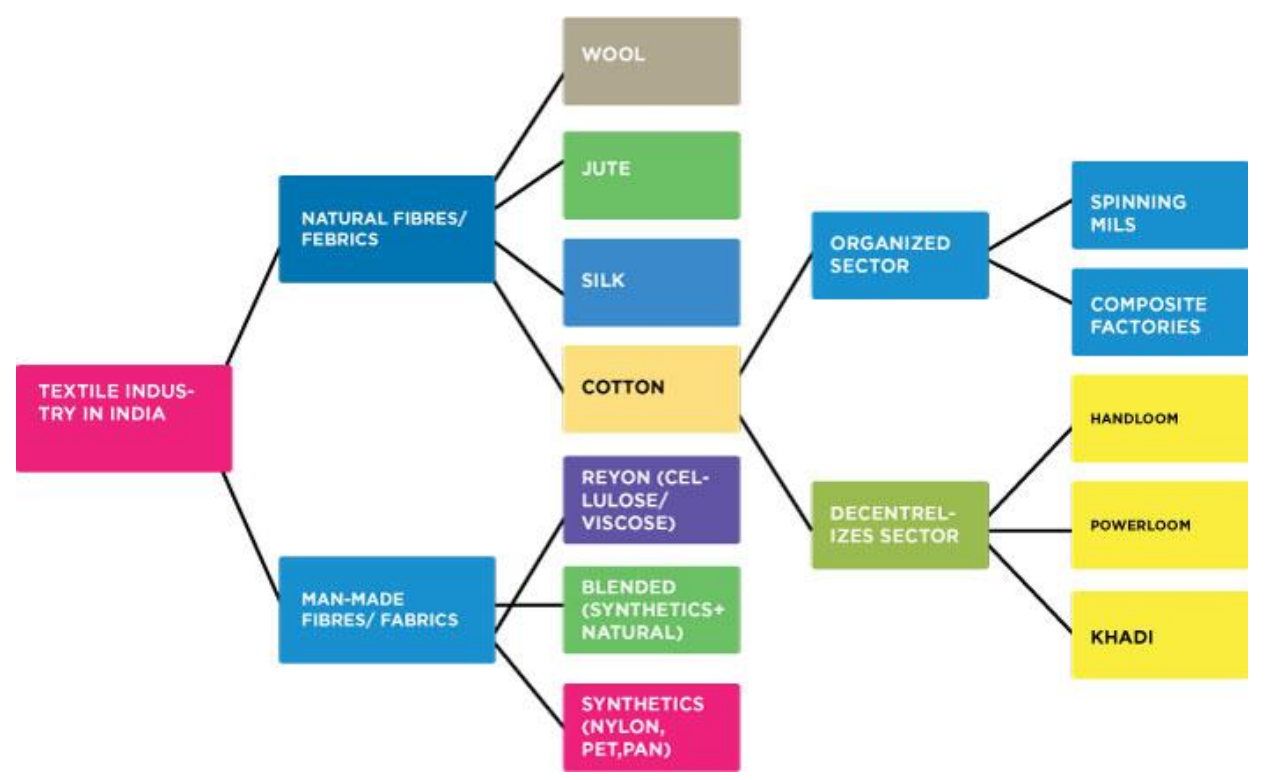

Figure 1 - Textile Industry in India (Source: textiletoday.com)

Indian textile is a leading industry in the manufacturing world. Clothes and all textiles product materials have become the basic needs of the society, these products have become the integrated part of daily human being needs, which never be separated. It is spreading all over the world and the demands of textile cannot be decrease, because increasing the population creating the opportunity for textile producers. Even it is providing employment to the weaker section of the society. From the era of Gandhi, it is continuing growing in terms of production as well as in terms of employment. Majority of workers are women they are earning its livelihood from this economic activity. This sector is highly informal or unorganized, spreading into different rural backward areas. It is more popular between the women housewives, because they are regularly meeting together sharing their social emotions along with generating income through this economic activity. Even this sector is also helpful in reducing the family dispute by providing the work to women so that they can utilize their time in economic opportunity rather than wasting time in unproductive family related issues.

Inclusiveness and Textile. Inclusive growth is the growth in which all things concerned for human welfare and development are incorporated. In context of India, diversity in the society by past categorical divide system cannot be ignore in the present time. The people belongs to different categories in India, still they are deprived from socio and economic development, we need to incorporate these people in the main stream of development through providing opportunities in terms of employment as well as providing economic perquisites benefit in lieu of money. Inclusive policy covers women, transgender, economical deprived peoples, and tribal section of the society for the overall human development of the country. To fulfilling the objective of inclusiveness of India the Textile is playing dominant role from the era of British India. From this era, Gandhi promoted khadi as movement of selfreliance for their people and currently the prime minister of India is also more emphasizing on textile products promotion world-wide through its self-brand image of khadi look. Majority of Informal units of textile is creating socio-economic inclusion opportunity in every state 
without any support of government. But for the social security of the unorganized sector workers still is far from socio-economic inclusion, because the government has not actual data about these small cottage units. The workers of these unorganized units are getting less wage as compare to other sectors, so these people are socially insecure and deprived from the basic medical health and education facilities.

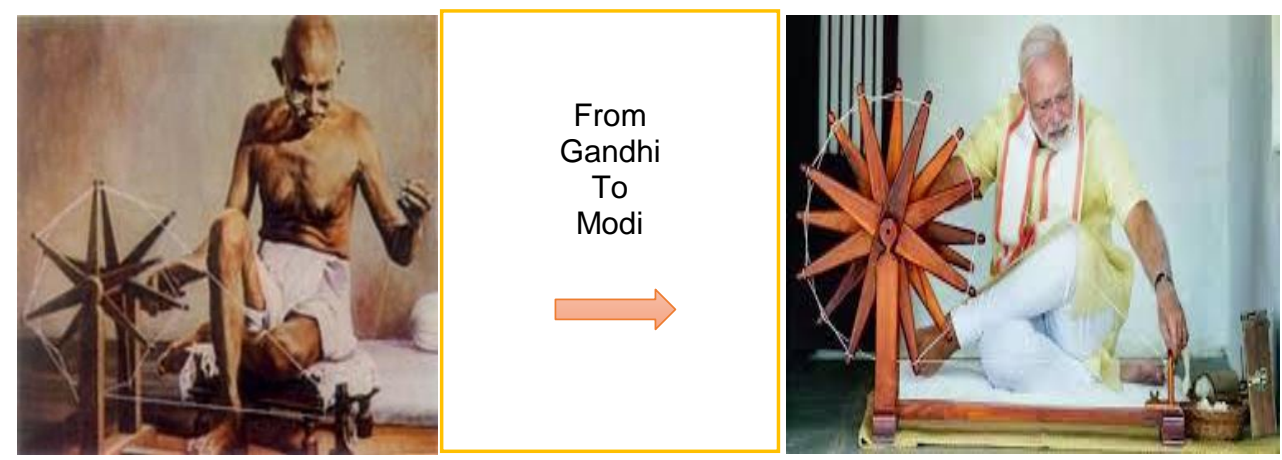

Figure 2 (Source: fibre2fashion.com \& financialexpress.com)

The Government is promoting khadi and textile for inclusiveness of society. From figure 2 , it is clearly showing the textile informal sector promotion by the legends of India, so the critical study of these figures, it is found that the unorganized sector of India is engine of economy and the textile is the playing dominant role to achieving the Gandhi objective of inclusive society development.

Textile and Corporate social responsibility. According to statistics reports of ministry of textile revealed that more than $90 \%$ textile units are unorganized so the discussion for CSR in this sector is become irrelevant because we are calling them informal units and informal units are the units, which are beyond any organization regulations. There are no labor rules, labor union, and no social security regulation for the workers, so only, the discussion can be move on the social responsibility of the textile informal sector. Responsibility for employee working conditions, health, environment friendliness and uncertainty.

The reason behind prosperity of ancient society not lies in welfare measure adopted by the early administration. It actually lies in fragmented and decentralized nature of industry instead of concentration of means of production in few hands. As today we called them as cottage industry. In early times every household acted as a cottage industry and producing some good that can earn them livelihood. So, inclusive growth was inevitable phenomena at that time. Inclusive growth is a type of growth that's including every section of society including most deprived one. So decentralization of mean of production had a credit of inclusive growth in ancient time. In medieval era, as industrial revolution progress, technology become so precise that everybody either not having access to it or unknown of it.

As a result household industry was incapable of competing with high capital and innovative industry, which later result in changing of decentralized to centralized nature of industry. And textile industry face changes from cottage or household industry to textile mills. Its hurts inclusiveness of means of production. As a result concentration of means of production emerges as an unstoppable tale. So from decentralized to centralized nature of industry, breakdown of inclusive societal structure occur which cause exclusion of a part of society from growth. The gap between two classes of society has widened as centralization is progressed. During British era as a result of "drain of wealth', the condition of society in economic term become so bad that a never occupied exclusion was created. The cottage industry that was surviving at that time were abolished due British dumping product manufacturing in their own country in India. So our cottage industry not able to stand in competition with British product.

After independence, in nehruvian era India opted for industry as prime moving force. So large capital asset were created for streamlining economic growth as per optimum level. Though it help in filling up gap created during British era by wealth drain policy of British. On 
data, it help in increase our economic growth "a quantitative analysis" but in term of economic development "a qualitative analysis" India were far lag behind. To develop economic development indicator financial inclusion and social inclusion are prerequisite.

In decade of 90's, liberalization, privatization, globalization (LPG) of 1991 gives a boost to economy. It help in changing the behavior of government from regulator to facilitator. It changes government control to market control. Big firm were established in private sector due ease of doing business by government. But as new public administration approach focus on welfare of deprived. So regulations were required for corporate sector to enforce and shows some social responsibility. Because government exit from the role of money creation to public service. So corporate social responsibility has taken place of cottage industry of ancient time. As our research focus on role of textile industry in developing of inclusive growth and corporate social responsibility.

Corporate Social Responsibility of Modi Industries after independence. In terms of corporate social responsibility of big textile units, this sector is not enough contributing in the social liabilities towards its employees. In the past, Modi Textile Industry was the renowned philanthropic legendry example for all companies in India. In 1980's the Modi industry was playing leading role in the area of corporate social responsibilities. Modinagar city, which is situated in Uttar Pradesh state of India was the famous for workers driven policies, still this city is the live witness of social responsibility of Modi textile industry.

Modi industry played a number of social responsibilities to uplift the livelihood of their employees. The major sources of responsibility were:

- Financial help for girls marriage;

- Established free educational institution from primary to higher education for children of workers and the local villagers;

- Financial aid in Funeral time of dependents;

- Medical facilities of family and dependents;

- Social security's scheme for all workers;

- Employment to worker's children after study;

- Separate Temples for the workers colonies.

Job Creation and Inclusive Growth. India's Demographic Dividend With a population of roughly 1.28 billion folks, Bharat is that the second most inhabited country within the world. Almost sixty six per cent of India's population - close to 850 million is of working age at the moment. The number is likely to extend by 169 million by the end of 2030 . This demographic dividend can permit Bharat to with success emerge as a manufacturer of labor intensive merchandise like textile and apparel within the predictable future. For reaping the rewards of the demographic dividend, Bharat needs to produce jobs at the rate of 1,000,000 jobs per month. India has to, therefore, grow at a rate of eight to10 per cent per year; and therefore the model of growth needs to be inclusive with associate absolute specialize in job creation.

Employment Potential. The textiles sector holds a significant worth and potential from the perspective of employment generation. The sector presently employs a lot of than five large integer folks directly and another 6.7 crores within the allied sectors like cotton and jute farming, sheep rearing, textile machinery, etc. table 2, supported information printed by Annual Survey of trade provides the comparable standing of textiles for employment creation vis-à-vis alternative sectors. As a thumb rule, it's probable that for associate investment of Rs. 1 crore in a fully integrated textile and attire manufacturing set-up, thirty jobs are created whereas for attire producing alone seventy jobs are created for each Rs. one large integer investment. As a matter of fact, the All Asian country Textile and Garment Industry Survey of 2011-12 puts the use per large integer rupees of investment figure for non-SSI garment units between sixty eight and 169. Unmistakably, the textiles sector is nonpareil once it involves worth for money (read investment) within the sphere of employment generation.

Inclusive growth. Aside its job creation role, this sector is additionally seamlessly aligned with Government initiatives on girl's empowerment. It's calculable that women represent regarding seventy per cent of the men within the attire sector. The sector conjointly provides job opportunities to millions within the beneath privileged sections of the society by 
giving them a means of stable financial gain associated an opportunity to lift their customary of living. Hence, for a rustic like Asian country, the importance of the textiles sector for employment creation is peerless. A majority of the Indian population resides in rural elements of Asian country wherever people don't have access to quality education and alternative basic facilities. As entry level job roles within the textiles sector generally don't need folks with high technical skills or instructional background, an individual from rural Asian country, can become employable within the textiles sector with a nominal coaching of three to 4 weeks solely. Structural Shifts in international Industry China has been the undisputed leader in international trade over the last three decades. Within the textiles and apparel phase particularly, China has maintained a dominant share of over 40 per cent over the last twenty years. After the economic condition of 2009, China's growth within the trade has slowed down from a median fifteen per cent to around four per cent in 2014. This trend is expected to continue additional within the future conjointly. Currently, China is vacating the global export market because of high wages and shift focused to the domestic market. Asian country stands an honest probability to capture a mammoth share of the space ceded by China in international textile and attire trade investing its raw material and men advantage.

Table 1 - Estimated Employment in Textile and Apparel Value Chain (In Millions)

\begin{tabular}{|c|c|c|c|}
\hline Sector / Industry & As on March 2011 & Projected for 2019 & $2018-19(P)$ \\
\hline \multicolumn{4}{|l|}{ Textiles sector } \\
\hline Cotton/Man-made Fiber/Yarn Textile/ Mill Sector & 1.4 & 1.61 & 1.58 \\
\hline Man-made Fiber/Filament Yarn Industry (incl. texturing industry) & 0.24 & 0.28 & 0.27 \\
\hline Decentralized Power-looms Sector & 5.08 & 5.84 & 5.71 \\
\hline Handloom Sector & 7 & 8.05 & 7.88 \\
\hline Knitting Sector & 0.45 & 0.52 & 0.51 \\
\hline Processing Sector & 0.44 & 0.51 & 0.50 \\
\hline Woolen Sector & 3.2 & 3.68 & 3.60 \\
\hline Ready Made Garment Sector (including Knitwear Sector) & 11.22 & 12.9 & 12.62 \\
\hline Sericulture & 7.7 & 8.86 & 8.67 \\
\hline Handicraft Sector & 8 & 9.2 & 9.00 \\
\hline \multicolumn{4}{|l|}{ Jute Industry } \\
\hline i) Organized Jute Industry & 0.26 & 0.3 & 0.29 \\
\hline ii) Decentralized Jute Industry & 0.2 & 0.23 & 0.23 \\
\hline Total (I) & 45.19 & 51.97 & 50.84 \\
\hline \multicolumn{4}{|l|}{ Allied Sector } \\
\hline \multicolumn{4}{|l|}{ Cotton } \\
\hline i) Cotton Agriculture & 20 & 23 & 22.50 \\
\hline ii) Cotton Ginning/Pressing & 1.3 & 1.5 & 1.47 \\
\hline iii) Cotton Trade & 19 & 21.85 & 21.38 \\
\hline Sub-Total & 40.3 & 46.35 & 45.34 \\
\hline Sheep rearing & 2.8 & 3.22 & 3.15 \\
\hline Jute Agriculture & 17 & 19.55 & 19.13 \\
\hline Textile machinery \& accessories & 0.1 & 0.12 & 0.12 \\
\hline Total (II) & 60.2 & 69.23 & 67.73 \\
\hline Grand Total $(\mathrm{I}+\mathrm{II})$ & 105.4 & 121.2 & 118.57 \\
\hline
\end{tabular}

Table 2 - Comparable standing of textiles for employment creation vis-à-vis other sector

\begin{tabular}{|c|c|c|c|}
\hline Manufacturing Sector & $\begin{array}{l}\text { Fixed Capital } \\
\text { (In Lakhs) }\end{array}$ & $\begin{array}{l}\text { Persons } \\
\text { Employed }\end{array}$ & $\begin{array}{l}\text { Employment per crore Rupees } \\
\text { investment }\end{array}$ \\
\hline Dairy products & 1203869 & 145601 & 12 \\
\hline Beverages & 2675247 & 158507 & 6 \\
\hline $\begin{array}{l}\text { Wearing apparel, except fur } \\
\text { apparel }\end{array}$ & 1280564 & 713833 & 56 \\
\hline Knitted and crocheted apparel & 1369141 & 264261 & 19 \\
\hline Paper and paper products & 642536 & 248529 & 39 \\
\hline Rubber products & 2668512 & 218754 & 8 \\
\hline Basic iron and steel & 40999661 & 650680 & 2 \\
\hline Electronic components & 421154 & 76619 & 18 \\
\hline General purpose machinery & 3417453 & 338964 & 10 \\
\hline Motor vehicles & 7088020 & 176523 & 2 \\
\hline
\end{tabular}


Textile Market Growth Projections. The expected high growth in exports apart, the rise in income of customers and their increasing propensity to pay on article of clothing things have been driving a integer growth of the domestic market. supported the emerging international and domestic market trends, it's expected that the Indian textile and attire market can grow from current level of US $\$ 119$ bn. to US $\$ 400$ bn. by 2025-26.

Table 3 - Indian textile and apparel market growth projections

\begin{tabular}{|c|c|c|c|}
\hline$n / n$ & 2015-16 & $2025-26$ & CAGR \\
\hline Exports & US\$ 40 bn. & US\$ 150 bn. & 14 per cent \\
\hline Domestic market & US\$ 79 bn. & US $\$ 250$ bn. & 12 per cent \\
\hline Total & US\$ $119 \mathrm{bn}$. & US $\$ 400$ bn. & 13 per cent \\
\hline
\end{tabular}

Creation and comprehensive Growth. Strategies taking into thought the unmatched potential for job creation in the textiles sector and therefore the opportunities emerging within the international market, the Government have developed a technique to foster growth and build an oversized number of jobs within the textile and attire sector. Additionally to the prevailing schemes that specialize in technology upgrade, infrastructure creation, and strengthening of ancient segments, the Government has given a special thrust to talent development. In order to make the Indian attire sector competitive, a special package for the Garmenting Sector has been free which is aimed toward removing the prevailing restrictions on productivity and conjointly at incentivizing job creation and exports.

Table 4 - Special Package for Garmenting Sector: Estimated Employment Generation over next 3 years

\begin{tabular}{|l|c|}
\hline \multicolumn{1}{|c|}{ Segment / Intervention } & $\begin{array}{c}\text { Employment Direct \& } \\
\text { Indirect (Lakhs) }\end{array}$ \\
\hline Measures to Enhance Competitiveness of the Apparel Industry & 9.7 \\
\hline 80JJAA Amendments & 12.25 \\
\hline Additional TUFS for garmenting & 9.5 \\
\hline Additional 3.67 per cent EPF contribution & \\
\hline Additional duty drawback for garments & 1.75 \\
\hline Labor law reforms & 10.7 \\
\hline Employment in upstream segments @ 35 per cent (yarn, fabric \& processing) & 56.4 \\
\hline Indirect Employment(@ 1:1.3) & 100.3 \\
\hline Total & \\
\hline \multicolumn{2}{|c|}{ Source: Internal Estimates, Ministry of Textiles, Government of India. } \\
\hline
\end{tabular}

Skilling individuals: making associate Enabling setting. Job creation needs high growth in the returning years. To realize this growth, giant scale investments in producing are needed. This, in turn, can increase the demand of sure-handed labor for this sector. To satisfy the demand of sure-handed labor, lots of focus has been given to ability development initiatives within the country. For the textiles sector, the Integrated ability Development theme (ISDS) for development of sure-handed force during this sector has been operational, that leverages the experience and reach of existing textile coaching establishments and additionally invitations non-public sector participation and participation of authorities agencies. As on first Gregorian calendar month 2016, 7.7100000 employees are trained beneath ISDS out of that five.06 (66 per cent) are absorbed within the trade. The whole target beneath ISDS is to coach fifteen 100000 employees by FY 2016-17. Moreover, skilling within the unorganized sector is promoted beneath loom Sector and Handicrafts Sector schemes of state of Asian country. Also, beneath the ability Asian country mission, a good and elaborate coaching framework has been enforced recently. For the textile and attire sector, 2 sector ability councils viz., Textiles sector ability Council and attire, Made-ups \& Home Furnishing Sector ability Council are fashioned.

Special Package for the Garmenting sector. The garmenting trade, that holds vast potential for job creation, has been beset with many inhibiting factors including unequal access to international markets, comparatively higher wage prices, restrictive labor laws 
obstructive productivity, inadequate incentives for investments and exports, etc. to interrupt the shackles and to spur growth within the garmenting trade, the govt. has delivered a special package for rising the fight of the Indian garmenting sector.

The recently approved package includes extra disadvantage for garment exports, labor reforms like introduction of mounted term employment, increase in overtime limit and easing of Section 80JJAA of revenue enhancement act to support employment within the garmenting sector. The govt. also will currently bear the whole twelve per cent of employer's worker Provident Fund (EPF) contribution for all the new staff for the primary 3 years. the availability of employees' contribution to EPF has been created optional for those earning but Rs. 15,000 per month which can cause more money in hand with the employees. The introduction of mounted term employment can facilitate increase the labor offer and employability within the garment sector throughout the height season of the trade. a set term working man are thought of at par with permanent workman in terms of operating hours, wages, allowances and statutory dues. The overtime cap per quarter has additionally been raised from fifty hours to one hundred hours which can cause augmented earnings for the employees. The new package for the garment sector is anticipated to come up with over one large integer jobs during this sector over a 3 year amount as given within the table 4 .

\section{CONCLUSION}

The anticipated upsurge in a job and also the creation of complete man-power base can attract massive scale investments, each domestic additionally as FDI, within the textiles sector and can serve to achieve the vision of the Hon'ble Prime Minister of creating Asian nation a worldwide producing hub. "India is unambiguously poised for re-casting the negative narrative and also the pessimism general within the world economy...by that specialize in social quality, by that specialize in long run goals and by investment in social and human capital". Through its recent initiatives within the Textile and attire Sector, the Indian Government has opened a brand new narrative - a narrative of optimism, of enhancing exports, of job creation, and of social transformation. But its role in social responsibility is critical; the main reason for this sector is to be unorganized.

\section{REFERENCES}

1. Akter, A. (2017) "Indian textile \& clothing industry- robust but lagging behind in achieving target”, https://www.textiletoday.com.bd/indian-textile-clothing-industry-robust-laggingbehind-achieving-target/ Accessed on 12 December 2018

2. Awasthi,Y. and Mawlood, H. A. K. (2018), "A Comparative Study Of Travelling Salesman Problem And Solution Using Different Algorithms Design Techniques In Kurdistan Region - Iraq", Journal of Advanced Research in Dynamical and Control Systems- JARDCS, Vol. 10. pp. 2731-2741.

3. Chaganti, V. K. (2014) "CSR Spending of Textile Industry in India", Samiksha, 5(1), pp. 20-24.

4. Dixit P, Ahmed, R. R. (2019), "Diversification of economy - an insight into economic development with special reference to Kurdistan's oil economy and agriculture economy", RJOAS, Vol. 1(85), January 2019 pp. 395-404.

5. Dixit, P. and Lal, R.C. (2016), "Role of Gandhi's Khadi Textile Industry Towards Inclusive Growth \& Corporate Social Responsibility”, Int. J. of Trade and Commerce-IIARTC, Vol. 5, No. 1, pp. $115-120$

6. Dixit, P. and Tyagi, A. (2015), "A Study of Downturn Trends of Crude Oil Price - An Economic Advantage for Indian Government and Consumers", Int. J. of Trade and Commerce-IIARTC, Vol. 4, No. 1, pp. 121-126.

7. Economic Times (January 2019) "Women entrepreneurs are major beneficiaries of Mudra scheme: Textiles Minister", http://economictimes.indiatimes.com/ Accessed on January 09,2019 
8. ICEC (2016), "Promoting Corporate Social Responsibility (CSR) in Indian Textile Industry by "Developing a CSR Framework for Indian MSME Industries, based on Best International CSR Practices"111, http://www.icec-council.org/wpcontent/uploads/2016/02/Study-on-Promoting-CSR-in-Indian-Textile-Industry.pdf Accessed on December 12, 2018

9. Ministry of Textile, Government of India (2018), "Annual Reports", http://texmin.nic.in/documents/study-report Accessed on October 03, 2018

10. Nasreen, V. Noorzia and Rao, S. Durga (2014), "Corporate Social Responsibility in Indian Textile Industry", MERC Global's International Journal of Social Science \& Management, Vol. 1, Issue 3, pp. 124-134

11. OFFICE OF THE DEVELOPMENT COMMISSIONER (HANDLOOMS) (2018), "Annual Reports", http://handlooms.nic.in/Default.aspx?ReturnUrl=\%2f Accessed on September 03, 2018

12. Szewczyk, M. (2016), "Corporate Social Responsibility in the Textile and Apparel Industry: Barriers and Challenges", http://jcrl.umk.pl/files/3315/0102/1371/Szewczyk.pdf Accessed on July 11, 2018

13. Tewari, M. (2006), "Adjustment in India's Textile and Apparel Industry: Reworking Historical Legacies in a Post-MFA World", https://journals.sagepub.com/doi/10.1068/a38279 Accessed on June03, 2018

14. Yojana October (2016) "Textile special issue", http://yojana.gov.in/Final\%20October\%20Yojana\%2017-9.pdf Accessed on July 15, 2018

15. Tandon, N. and Reddy, E. E. (2013), "A study on emerging trends in textile industry in India", International Journal of Advancements in Research \& Technology, Volume 2, Issue 7, pp. 267-276. 